\title{
ANALISIS CEMARAN BAKTERI COLIFORM PADA SUSU KEDELAI TANPA MEREK
}

\author{
Rizki Nisfi Ramdhini ${ }^{1^{*}}$ \\ ${ }^{1}$ STIKES Muhammadiyah Pringsewu Lampung, Indonesia \\ *Email: rizkinisfi2018@gmail.com
}

Received: April 17 $7^{\text {th }}$ 2019. Accepted: June 30 ${ }^{\text {th }}, 2019$. Published: June $30^{\text {th }}, 2019$

\begin{abstract}
Soybeans are a source of high-quality vegetable protein for human consumption or made into products including soy milk. Soy milk which is poorly processed can be contaminated with bacteria that cause disease, one of which is the Coliform bacteria group. Coliform is a group of bacteria that are contained in large quantities in human and animal feces, so these bacteria are often used as indicators of the quality of food and water. Coliform bacteria can cause various diseases, one of which is diarrhea. The purpose of this study was to determine Colifirm bacterial contamination in unbranded soy milk. The type of research used is descriptive experimental research. The samples were analyzed using the total plate number (ALT) and the Most Probable Number (MPN) method. The results are compared with the ALT and MPN standard values with the Indonesian National Standard 06.8-7388-2009. The results showed that 5 of the 10 samples tested were above the standard, because the number of microbes $>5 \times 104$ colonies / $\mathrm{ml}$ (standard $5 \times 104$ colonies / $\mathrm{ml}$ ), and the value of MPN > $3 / \mathrm{ml}$ (standard $<3 / \mathrm{ml}$ ). Based on data analysis it can be concluded that half of the samples taken contain coliform bacteria contamination.
\end{abstract}

Keywords: Contamination; Coliform; Soy milk.

\begin{abstract}
Abstrak
Kedelai merupakan sumber protein nabati berkualitas tinggi untuk konsumsi manusia atau dibuat menjadi produk termasuk susu kedelai. Susu kedelai yang olahannya buruk dapat terkontaminasi bakteri penyebab penyakit, salah satunya adalah kelompok bakteri Coliform. Coliform adalah sekelompok bakteri yang terkandung dalam jumlah besar dalam kotoran manusia dan hewan, sehingga bakteri ini sering digunakan sebagai indikator kualitas makanan dan air. Bakteri Coliform dapat menyebabkan berbagai penyakit, salah satunya adalah diare. Tujuan dari penelitian ini adalah untuk mengetahui cemaran bakteri Colifirm pada susu kedelai tidak bermerek. Jenis penelitian yang digunakan adalah penelitian deskriptif eksperimental. Sampel dianalisis dengan menggunakan angka lempeng total (ALT) dan metode Most Probable Number (MPN). Hasilnya dibandingkan dengan nilai standar ALT dan MPN dengan Standar Nasional Indonesia 06.8-7388-2009. Hasil penelitian menunjukkan bahwa 5 dari 10 sampel yang diuji berada diatas standar, karena jumlah mikroba > $5 \times 104 \mathrm{koloni} / \mathrm{ml}$ (standar 5x104 koloni/ml), dan nilai MPN $>3 / \mathrm{ml}$ (standar $<3 / \mathrm{ml}$ ). Berdasarkan analisis data dapat disimpulkan bahwa setengah dari sampel yang diambil mengandung cemaran bakteri Coliform.
\end{abstract}

Kata Kunci: Cemaran; Coliform; Susu Kedelai.

\section{PENDAHULUAN}

Kedelai merupakan salah satu tanaman pangan penghasil protein nabati yang sangat penting menjadikan makanan-makanan hasil olahan kedelai sebagai konsumsi utama untuk memenuhi kebutuhan protein keluarga (Fatmalia \& Crystin, 2017). Salah satu diantaranya adalah susu kedelai. Susu kedelai merupakan susu nabati yang kaya provitamin A, Vitamin 
B kompleks, mineral, karbohidrat, posfor dan zat besi. Selain itu, susu kedelai juga memiliki kandungan asam lemak tak jenuh seperti esitin dan asam linolenat serta bebas laktosa. Oleh karena itu, susu kedelai juga dapat digunakan sebagai pengganti susu sapi terkait nilai gizi yang dikandung hampir sama (Singh \& Singh, 2009; Widodo, 2016). Beberapa komoditi kacang-kacangan di Indonesia telah digunakan sebagai bahan dasar untuk membuat susu yang dikenal sebagai susu nabati.

Susu nabati yang umum ditemukan dipasaran adalah susu kedelai, baik dalam kemasan bermerek maupun yang tidak bermerek. Dimana kemasan yang tidak bermerek tersebut tidak mencantumkan surat izin produksinya sehingga sebagian masyarakat masih meragukan keamanannya untuk dikonsumsi (Santri, Nuryanti, \& Naid, 2015).Susu kedelai tidak bermerek sebagian besar pengolahannya masih dilakukan secara tradisional. Akibatnya, produk olahan kedelai rentan mengalami kontaminasi bakteri Coliform .Hal tersebut dikarenakan peralatan yang digunakan tidak steril dan proses perebusan yang tidak maksimal $\left(<100^{\circ} \mathrm{C}\right)($ Buckle, 2009). Sesuai dengan hasil penelitian yang dilakukan sebelumnnya oleh Sirait (Sirait, 2009), bahwa pengolahan susu kedelai pada usaha kecil di kota Medan belum memenuhi syarat kesehatan. Hal tersebut dikarenakan semua produsen susu kedelai belum menerapkan seluruh prinsip higienitas dalam pengolahan.

Bakteri Coliform merupakan golongan mikroorganisme yang lazim digunakan sebagai indikator adanya kontaminan yang berasal dari kotoran (Fatmalia \& Bayyinah, 2018). Bakteri Coliform, yang terdiri dari Serratia, Hafnia, Citrobacter, Enterobacter, Klebssiella, dan Escherichia Coli merupakan kelompok bakteri yang digunakan sebagai indikator kualitas air, makanan maupun produk susu yang tercemar (Chaudhari, Patel, Tandel, \& Vibhuti, 2017). Bakteri Coliform dengan jumlah berlebih pada susu kedelai jika dikonsumsi dapat menyebabkan gangguan kesehatan (gastroenteritis) (Pratiwi, 2015).

Menurut Standar Nasional Indonesia (SNI) No. 06.8-7388-2009 persyaratan cemaran mikroba pada produk kedelai yaitu mengandung angka lempeng total bakteri maksimal $5 \times 10^{4}$ koloni/mL, nilai MPN bakteri Coliform $<3 / \mathrm{mL}$, Salmonella sp negatif $/ 25$ $\mathrm{mL}$, Staphylococcus aureus $1 \times 10^{2} \mathrm{koloni} / \mathrm{mL}$, Bacillus cereus $1 \times 10^{3} \mathrm{koloni} / \mathrm{mL}$ dan kapang $5 \times 10^{1} \mathrm{koloni} / \mathrm{mL}$.

Berdasarkan penelitian terdahulu, menganalisis cemaran bakteri Coliform dibeberapa bahan pokok sehari-hari, seperti tempe (Khaq \& Dewi, 2016), daging ayam (Juwita, Haryani, \& Jose, 2014) dan sapi (Jasmadi, Haryani, \& Jose, 2014), saos tomat (Mansauda, Fatimawali, \& Kojong, 2014) bahkan di es dung-dung (Putri \& Kurnia, 
2018) serta cincau hitam (Fatmalia \& Bayyinah, 2018) juga terdapat pencemaran bakteri Coliform. Di beberapa depot air minum isi ulang juga terjadi pencemaran bakteri Coliform (Alwi \& Maulina, 2012; Bambang, Fatimawali, \& Kojong, 2014; Pakpahan, Picauly, \& Mahayasa, 2015) di beberapa daerah di Indonesia. Perbedannya adalah penelitian mencoba menganalisis cemaran bakteri Coliform pada susu kedelai tanpa merk.

Penelitian selanjutnya yaitu menganalisis mikrobiologi susu kedelai tanpa merek di Kabupaten Maros Sulawesi Selatan (Santri et al., 2015) dan menganalisis bakteri Escherichia Coli pada susu kedelai bermerek dan tanpa merekdi kota surakarta (Ismail, 2012). Kebaruan penelitian ini yaitu untuk menganalisis susu kedelai terhadap cemaran bakteri Coliform di daerah yang berbeda, yaitu daerah Pringsewu, Lampung.

Berdasarkan penelitian terdahulu, maka perlu dilakukan pemeriksaan mikrobiologi terhadap susu kedelai tidak bermerek, khususnya di Pringsewu Lampung. Lokasi tersebut dipilih karena hingga kini belum ada penelitian yang dilaporkan sebelumnya guna memantau secara berkala untuk menjamin ketersediaan susu kedelai yang sehat dan aman dikonsumsi masyarakat. Oleh karena itu dalam penelitian ini akan dilakukan pengujian cemaran bakteri Coliform pada susu kedelai yang dijual di Pringsewu Lampung berdasarkan Angka Lempeng Total (ALT), cemaran bakteri Coliform dan mengidentifikasi adanya bakteri Escherichia Coli.

\section{METODE PENELITIAN}

Jenis penelitian ini bersifat eksperimental dengan pemeriksaan Laboratorium yang dilakukan di UPTD Dinas Kesehatan Kota Bandar Lampung. Sampel susu kedelai tanpa merek diambil secara accidental sampling pada bulan Januari 2019, sebanyak sepuluh sampel. Lokasi pengambilan sampel dilakukan di Pasar induk Pringsewu dan Pasar Terminal Pringsewu.

Pemeriksaan secara laboratorium pada sampel susu kedelai meliputi penentuan Angka Lempeng Total (ALT) dan penentuan jumlah bakteri Coliform. Penentuan ALT dilakukan sesuai dengan prosedur uji cemaran mikroba SNI No. 06.8-7388-2009, menggunakan medium Nutrient Agar (NA) melalui pengenceran sampel secara bertingkat $10^{1}-10^{-4}$, kemudian diinkubasi $37^{\circ} \mathrm{C}$ selama 24 jam. Penentuan ALT mengacu pada persyaratan produk kedelai yaitu total bakteri maksimal $5 \times 10^{4}$ koloni/mL.

Pengujian bakteri Coliform meliputi uji praduga (presumtif test) yang merupakan tes pendahuluan ada tidaknya bakteri golongan Coliform menggunakan medium Mac Conkey 
Broth (MCB), selanjutnya dilakukan uji konfirmasi (confirmative test) menggunakan medium Brilliant Green Lactose Bile (BGLB) 2\%. Terbentuknya gas pada tabung durham dalam media BGLB 2\% memperkuat adanya bakteri Coliform. Jumlah bakteri Coliform didapatkan dari tabel Most Probable Number (MPN), yang memberikan nilai duga terdekat dengan kombinasi tabung yang positif dan tabung yang negatif pada uji konfirmasi. Penentuan status cemaran bakteri Coliform mengacu pada SNI No. 06.8-7388-2009 terkait persyaratan cemaran bakteri Coliform pada produk kedelai yaitu $<3 / \mathrm{mL}$

\section{HASIL DAN PEMBAHASAN}

\section{Penentuan Angka Lempeng Total (ALT)}

Berdasarkan penelitian yang telah dilakukan pada 10 sampel susu kedelai tanpa merek dari pedagang di Pasar Induk Pringsewu dan Pasar Terminal Pringsewu, angka lempeng total (ALT) sampel susu kedelai tanpa merek dapat dilihat pada Tabel 1.

Tabel 1. Angka Lempeng Total (ALT) Susu Kedelai Tanpa Merek

\begin{tabular}{cccc}
\hline $\begin{array}{c}\text { Kode } \\
\text { Sampel }\end{array}$ & $\begin{array}{c}\text { Hasil Perhitungan } \\
(\text { Koloni/ml) }\end{array}$ & $\begin{array}{c}\text { Persyaratan } \\
(\text { Koloni/ml) }\end{array}$ & Keterangan \\
\hline A & $7,1 \times 10^{3}$ & $5 \times 10^{4}$ & MS \\
B & $6.2 \times 10^{4}$ & $5 \times 10^{4}$ & TMS \\
C & $5,3 \times 10^{4}$ & $5 \times 10^{4}$ & TMS \\
D & $5.1 \times 10^{4}$ & $5 \times 10^{4}$ & TMS \\
E & $6.4 \times 10^{4}$ & $5 \times 10^{4}$ & TMS \\
F & $6.1 \times 10^{4}$ & $5 \times 10^{4}$ & TMS \\
G & $7.4 \times 10^{3}$ & $5 \times 10^{4}$ & MS \\
H & $8.5 \times 10^{3}$ & $5 \times 10^{4}$ & MS \\
I & $6.7 \times 10^{3}$ & $5 \times 10^{4}$ & MS \\
J & $7.3 \times 10^{3}$ & $5 \times 10^{4}$ & MS \\
\hline
\end{tabular}

TMS: Tidak Memenuhi Syarat

MS : Memenuhi Syarat

Perhitungan total bakteri dipilih berdasarkan jumlah koloni yang tumbuh diantara 30-300. Hal tersebut dikarenakan jika jumlah koloni > 300 kemungkinan besar terjadi kesalahan perhitungan, begitu pula untuk jumlah koloni <30 sehingga tidak layak untuk disertakan dalam perhitungan ALT. Selanjutnya apabila memenuhi syarat perhitungan total bakteri 30-300 koloni dimasukkan ke dalam pembagian pengenceran tertinggi dibagi dengan pengenceran terendah (Bambang et al., 2014). Pada penelitian ini dilakukan pengenceran bertingkat yaitu $10^{1}-10^{-4}$. Hal ini dilakukan untuk mendapatkan konsentrasi yang berbeda dan koloni tumbuh dengan terpisah, sehingga memudahkan dalam 
perhitungan koloni bakteri terutama pada sampel dengan cemaran yang sangat tinggi. Selain itu untuk mengurangi tingkat kontaminasi sehingga memudahkan pengamatan bakteri atau koloni yang tumbuh serta untuk menginaktifkan pengawet yang ada dalam sampel.

Berdasarkan hasil analisis angka lempeng total (ALT) sampel susu kedelai tanpa merek yang tertera pada tabel 1 menunjukkan bahwa sampel B, C, D, E dan F tidak memenuhi persyaratan ALT menurut ketentuan Standar Nasional Indonesia (SNI) No. 06.87388-2009, yakni total bakteri maksimal $5 \times 10^{4} \mathrm{koloni} / \mathrm{ml}$.

\section{Penentuan Jumlah Bakteri Coliform}

Tabel 2. Hasil Perhitungan Bakteri Coliform Pada Susu Kedelai Tanpa Merek

\begin{tabular}{cccccc}
\hline No & $\begin{array}{c}\text { Kode } \\
\text { Sampel }\end{array}$ & Parameter & $\begin{array}{c}\text { Hasil } \\
\text { Pemeriksaan }\end{array}$ & $\begin{array}{c}\text { Kadar Maksimal yang } \\
\text { Diperbolehkan }\end{array}$ & Ket* \\
\hline 1 & A & Coliform & $<3$ & $<3 / \mathrm{ml}$ & MS \\
2 & B & Coliform & $>2400$ & $<3 / \mathrm{ml}$ & TM \\
3 & C & Coliform & $>2400$ & $<3 / \mathrm{ml}$ & TM \\
4 & D & Coliform & $>2400$ & $<3 / \mathrm{ml}$ & TM \\
5 & E & Coliform & $>2400$ & $<3 / \mathrm{ml}$ & TM \\
6 & F & Coliform & $>2400$ & $<3 / \mathrm{ml}$ & TM \\
7 & G & Coliform & $<3$ & $<3 / \mathrm{ml}$ & MS \\
8 & H & Coliform & $<3$ & $<3 / \mathrm{ml}$ & MS \\
9 & I & Coliform & $<3$ & $<3 / \mathrm{ml}$ & MS \\
10 & J & Coliform & $<3$ & $<3 / \mathrm{ml}$ & MS \\
\hline
\end{tabular}

Berdasarkan pemeriksaan bakteri Coliform pada penelitian ini menggunakan metode Most Probable Number (MPN) melalui uji praduga (presumptive test) dan uji konfirmasi (confirmative test). Metode MPN merupakan metode perhitungan bakteri Coliform berdasarkan jumlah perkiraan terdekat dengan nilai duga dengan kombinasi jumlah tabung positif tiap seri yang mengacu pada tabel MPN (Hartanti, 2015).

Berdasarkan hasil perhitungan bakteri Coliform pada tabel 2 dapat diketahui bahwa sampel B, C, D, E dan F memiliki jumlah MPN Coliform > 3/ml. Hasil tersebut menunjukkan bahwa semua sampel tersebut jika dibandingkan dengan persyaratan SNI No. 06.8-7388-2009 terkait cemaran bakteri produk kedelai, tidak memenuhi persyaratan untuk dikonsumsi karena telah tercemar bakteri Coliform.

Terdapat beberapa faktor yang mempengaruhi susu kedelaidapat terkontaminasi bakteri Coliform, diantaranya terkait pengolahan susu kedelai masih tradisional, minimnya pengetahuan sanitasi dan higiene yang rendah sehingga berpotensi terjadi kontaminasi 
bakteri patogen. Kontaminasi bakteri Coliform dapat terjadi melalui bahan baku, bahan pembantu, bahan tambahan, bahan pengemas, peralatan dan lingkungan. Kontaminasi terhadap air susu kedelai dapat menyebabkan diare (Soeparno, Rihastuti, Triatmojo, \& Indratiningsih, 2011).

\section{SIMPULAN DAN SARAN}

Berdasarkan hasil dan pembahasan di atas, dapat disimpulkan bahwa terdapat 5 sampel susu kedelai tanpa merek tidak memenuhi persyaratan SNI No. 06.8-7388-2009 tentang produk susu kedelai, yaitu sampel B, C, D, E dan E atau dengan kata lain, setengan dari sampel yang diambil mengandung cemaran bakteri Coliform.

Saran yang diberikan adalah agar masyarakat, terutama para penjual agar dapat menjaga kebersihan dalam proses pengolahan susu kedelai terutama dalam tahap penyiapan peralatan dan bahan baku, pengemasan serta pemasaran dan bagi peneliti, sebaiknya dilakukan penelitian lebih lanjut mengenai identifikasi bakteri Coliform terhadap susu kedelai tanpa merek.

\section{DAFTAR PUSTAKA}

Alwi, M., \& Maulina, S. (2012). Pengujian Bakteri Coliformdan Escherichia Colipada Beberapa Depot Air Minum Isi Ulang di Kecamatan Palu Timur Kota Palu. Biocelebes, 6(1), 40-47.

Bambang, A. G., Fatimawali, \& Kojong, N. (2014). Analisis Cemaran Bakteri Coliformdan Identifikasi Escherichia Colipada Air Isi Ulang dari Depot di Kota Manado. Pharmacon: Jurnal Ilmiah Farmasi Jurnal Ilmiah Farmasi, 3(3), 325-334.

Buckle. (2009). Ilmu Pangan. Jakarta: UI Press.

Chaudhari, V. J., Patel, N. K., Tandel, B. M., \& Vibhuti, C. (2017). Effect of Foliar Spray Of Micronutrients on Yield Of Cauliflower (Brassica Oleracea L. Var. Botrytis). International Journal of Chemical Studies, 5(4), 2110-2112.

Fatmalia, N., \& Bayyinah, R. (2018). Deteksi Cemaran Bakteri Coliformpada Sampel Cincau Hitam dengan Variasi Lama Waktu Penyimpanan. Jurnal Sains, 8(16), 22 27.

Fatmalia, N., \& Crystin, C. N. (2017). Pengaruh Lama Penyimpanan Susu Kedelai pada Suhu Kulkas terhadap Cemaran Bakteri Coliformdengan Menggunakan Metode MPN. Jurnal Sains, 7(14), 23-29.

Hartanti, A. S. (2015). Mikrobiologi Kesehatan. Ed. I. Yogyakarta: CV. Andi Offset. 
Ismail, D. (2012). Uji Bakteri Escherichia Colipada Minuman Susu Kedelai Bermerek dan Tanpa Merek di Kota Surakarta. Universitas Muhammadiyah Surakarta.

Jasmadi, Haryani, Y., \& Jose, C. (2014). Prevalensi Bakteri Coliformdan Escherichia Colipada Daging Sapi Yang Dijual di Pasar Tradisional dan Pasar Modern di Kota Pekanbaru. JOM FMIPA, 1(2), 31-39.

Juwita, U., Haryani, Y., \& Jose, C. (2014). Jumlah Bakteri Coliformdan Deteksi Escherichia Colipada Daging Ayam di Pekanbaru. JOM FMIPA, 1(2), 48-55.

Khaq, K. N., \& Dewi, L. (2016). Deteksi Cemaran Bakteri Koliform dan Salmonella Sp. pada Tempe yang Dikemas Daun Pisang di Daerah Salatiga. Agric, 28(1), 79-86.

Mansauda, K. L. R., Fatimawali, \& Kojong, N. (2014). Analisis Cemaran Bakteri Coliformpada Saus Tomat Jajanan Bakso Tusuk yang Beredar di Manado. Pharmacon: Jurnal Ilmiah Farmasi, 3(2), 37-44.

Pakpahan, R. S., Picauly, I., \& Mahayasa, I. N. W. (2015). Cemaran Mikroba Escherichia Colidan Total Bakteri Koliform pada Air Minum Isi Ulang. KESMAS: Jurnal Kesehatan Masyarakat Nasional, 9(4), 300-307.

Pratiwi, R. H. (2015). Distribusi Bakteri Colifom di Situ Cilodong Depok Jawa Barat. Faktor Exacta, 6(4), 290-297.

Putri, A. M., \& Kurnia, P. (2018). Identifikasi Keberadaan Bakteri Coliformdan Total Mikroba dalam Es Dung-Dung di Sekitar Kampus. Media Gizi Indonesia, 13(1), 41-48.

Santri, Nuryanti, S., \& Naid, T. (2015). Analisis Mikrobiologi Beberapa Susu Kedelai Tanpa Merek yang Beredar di Kabupaten Maros Sulawesi Selatan. As-Syifaa, 7(2), $130-138$.

Singh, J., \&Singh, R. (2009). Optimization and Formulation of Orodiversible Tablets of Meloxicam. Tropical Journal Of Pharmacetical Research, 8(2), 153-159.

Sirait, E. U. (2009). Hygiene Sanitasi Pengolahan dan Pemeriksaan Escherichia Colidalam Susu Kedelai pada Usaha Kecil di Kota Medan. Universitas Sumatra Utara.

Soeparno, Rihastuti, S., Triatmojo, \& Indratiningsih. (2011). Dasar Teknologi Hasil Ternak. Yogyakarta: Universitas Gadjah Mada.

Widodo, S. (2016). Bakteri yang Sering Mencermari Susu: Deteksi, Patogenesis, Epidemiologi, dan Cara Pengendaliannya. Jurnal Penelitian dan Pengembangan Pertanian, 29(3), 96-100. 